\title{
STUDY ON HYDROGEOLOGICAL ASPECT OF GALANG SUB-DISTRICT, BATAM CITY FOR ACCEPTANCE OF PROSPECTIVE NPP SITES
}

\section{STUDI ASPEK HIDROGEOLOGI KECAMATAN GALANG KOTA BATAM UNTUK KEBERTERIMAAN CALON TAPAK PLTN}

\author{
Siti Alimah ${ }^{1}$, Euis Etty Alhakim¹, Hadi Suntoko ${ }^{1}$, Sunarko$^{1}$, Mudjiono $^{1}$ \\ ${ }^{1}$ Center for Assessment of Nuclear Energy System \\ e-mail: alimahs@batan.go.id
}

\begin{abstract}
This is a preliminary study in the selection of Nuclear Power Plant (NPP) site in Batam's Barelang area to support industrial growth in the area in the future. The initial site selection was conducted in 2015 and 2017 in the pre-survey phase, considering hydrogeological aspect. The results of previous research showed four potential areas, namely Pasir Panjang Beach, Tanjung Batu, Dapur 3 and Tanjung Rame. The hydrogeological aspect plays an important role in the consideration of site acceptance. This is related to the consideration of potential flow of radioactively contaminated groundwater seepage in the site area, in the event of a potential release. The acceptance of the NPP site from the hydrogeological aspect is based on the site's permeable geological formation and porosity condition, where groundwater can be stored. The purpose of the study was to assess the potential site in Galang Subdistrict, Batam City based on hydrogeological aspects which include surface geology, groundwater productivity and rock porosity. Research methods include primary and secondary data collection, literature review and ranking analysis. The results showed that Tanjung Batu, Dapur 3 and Tanjung Rame could be chosen as the potential sites for NPP based on the hydrogeological aspect. The three regions have surface geology in the form of sandstone, clay and claystone rock with medium rock porosity level and medium groundwater productivity. Pasir Panjang Beach is less preferable because it has a high porosity of rocks with the productivity of aquifers is being spread widely.
\end{abstract}

Key Words: Hydrogeology; Site selection; Acceptance of NPP site

\begin{abstract}
Abstrak
Penelitian ini merupakan kajian awal dalam kegiatan pemilihan tapak PLTN di Kawasan Barelang Kota Batam, dalam rangka mendukung pertumbuhan industri di masa mendatang di wilayah tersebut. Pemilihan tapak awal telah dilakukan tahun 2015 dan 2017 dalam tahap pra-survei yang diantaranya didasarkan pada aspek hidrogeologi. Hasil penelitian sebelumnya diperoleh empat tapak potensial yaitu Pantai Pasir Panjang, Tanjung Batu, Dapur 3 dan Tanjung Rame. Aspek hidrogeologi mempunyai peranan cukup penting dalam pertimbangan keberterimaan tapak. Hal ini terkait pertimbangan potensi transport rembesan air tanah yang terkontaminasi radioaktif dalam wilayah tapak, jika terjadi pelepasan potensial. Keberterimaan tapak PLTN dari aspek hidrogeologi adalah tapak memiliki formasi geologi bersifat permeabel dan kondisi porositas batuan dimana air tanah dapat tersimpan. Tujuan studi adalah mengkaji tapak potensial di Kecamatan Galang, Kota Batam berdasar aspek hidrogeologi yang meliputi geologi permukaan, produktivitas air tanah dan porositas batuan. Metode penelitian meliputi pengumpulan data primer, sekunder, kajian literatur dan analisis dengan pembobotan. Hasil penelitian menunjukkan bahwa Tanjung Batu, Dapur 3 dan Tanjung
\end{abstract}


Rame dapat menjadi pilihan untuk tapak potensial PLTN berdasar aspek hidrogeologi. Ketiga daerah tersebut memiliki geologi permukaan berupa batu pasir, lempung dan batu lempung dengan tingkat porositas batuan menengah dengan produktivitas air tanah sedang. Sedangkan Pantai Pasir Panjang memiliki tingkat kelayakan yang lebih rendah karena memiliki tingkat porositas batuan yang tinggi dengan produktivitas akuifer sedang menyebar luas.

Kata kunci : Hidrogeologi; Pemilihan tapak; Keberterimaan tapak PLTN

Received : 14 July 2020, Revised : 17 August 2020, Accepted : 21 August 2020

\section{INTRODUCTION}

Presidential Regulation No. 87 of 2011 regulates the Spatial Planning (RTR) of the Batam, Bintan, Karimun (BBK) area which is a strategic area in the Riau Islands ${ }^{1)}$. Regional growth in the Riau Islands continues to increase into industrial, trade, and ship transfer areas as well as tourism so it is expected to require a large number of electricity supply. In order to increase the supply of electricity, NPP (Nuclear Power Plant) can be an alternative for the electricity source. Batam Free Zone Authority (BP BATAM) and National Nuclear Energy Agency (BATAN) have signed an agreement in the form of a Memorandum of Understanding (MOU) related to preliminary study activities for the construction of NPP in Batam, Rempang and Galang Islands, which are contained in the Decree of the BP BATAM Chairman No. 77 of 20152). Presidential Regulation No.46 of 2013 states that one of the tasks of BATAN in the field of Nuclear Energy Technology is to carry out the formulation and policy in the Field of Nuclear Energy Technology Development, including NPP development plans ${ }^{3)}$. Based on this, BATAN through the Decree of the Chairman of BATAN No. 14 of 2013 appointed PKSEN (Center for Nuclear Energy System) as one of the units in BATAN that is tasked with carrying out site data assessment and implementation of the nuclear energy system.

A preliminary study of the NPP in the Barelang area was conducted in 2015 and 2017. The initial site pre-survey results for geological aspects, supported by land use, geography and topography conditions, and demographics have identified several regions of interest namely Tanjung Kelingking on Rempang Island, Sijantung Village on the West Coast of Galang Island, Tanjung Batu and Tanjung Rame on the East Coast of Galang Island ${ }^{4}$. Following further surveys on those four regions as well as subsequent scoring and weighting on seismicity aspects including surface faulting, seismicity, and geology/lithology, several potential sites were identified, namely Pasir Panjang Beach, Tanjung Batu, Dapur 3 and Tanjung Rame ${ }^{5}$.

Another aspect that also needs to be considered in the NPP site survey to determine the feasibility of the site related to safety aspect is the hydrogeological aspects $^{6,7,8)}$. Based on the Code of Federal Regulation (10 CFR part 52), new NPP installations must have a safety analysis report, which includes evaluating the site's hydrogeological aspect to determine the effect of an accident of radionuclide effluent release in groundwater and surface water. Groundwater is water that is found in layers of soil with small or large pores or found in rocks below the surface of the soil. Hydrogeological aspects study for NPP is to guarantee the safety of the community and the environment due to the potential for radioactive release from NPP, both under normal operating conditions and accident conditions $^{9}$. Site feasibility of NPP needs to consider site safety and the environment ${ }^{10}$. The IAEA safety guide NS-G-3.2 stated that among the criteria relating to the site and environmental characteristics, is the influence of the transfer of radioactive material released from nuclear installations into the environment. According to NS-G-3.2, the phenomenon of the dispersion of radioactive material in surface water and groundwater must be considered ${ }^{111}$.

This study aims to assess the area in Galang Subdistrict, Batam City based on hydrogeological aspects which include surface geology, groundwater productivity and rock porosity. The method used in the study is the collection of secondary and primary data, literature reviews and scoring/evaluation and analysis. The result of the study is expected to be used as an input for policymakers in determining the location of potential NPP sites in Batam based on hydrogeological aspects. 


\section{METHODOLOGY}

\section{Data Collection, Evaluation and Analysis}

The method used in this research is secondary data collection from related literature such as reports on the activities of several central and local government agencies, scientific writing, reference data, literature review and field confirmation to obtain primary data and analysis. Field confirmation is done with a description of the rock outcrops around the observation. The analysis is done by ranking based on weighting dan score ${ }^{12,13)}$. In this study, ranking is needed as a basis for comparing potential sites in order to obtain preferred potential sites ${ }^{14)}$. The first step is to define the score against hydrogeological aspect parameters namely surface geology, the porosity of rocks and groundwater productivity. Then calculated the weight percentage and do the ranking. The next step is mapping the potential sites using a Geographic Information System (GIS) to be more informative. The parameters are divided into three classifications which indicate the level of eligibility as a potential NPP site in Galang sub-district, Batam City.

\section{Time and Research Area}

The research activity to obtain primary data was carried out in January - December 2017. The research area included Galang Island and Rempang Island which were administratively located in Galang subdistrict, Batam City, Riau Islands Province. Galang sub-district is directly adjacent to North Bintan District in the north and Senayang District in the southern part. The eastern part is directly bordered by the city of Tanjung Pinang and the western part is bordered by the District of Bulang. The location is situated between $0^{\circ} 29^{\prime}$ South Latitude and $04^{\circ} 40^{\prime}$ South Latitude and between $103^{\circ} 22^{\prime}$ East Longitude and $109^{\circ} 4^{\prime}$ East Longitude, as shown in Figure 1.

Rempang Island area is about $165 \mathrm{~km}^{2}$, the second largest island in the Batam City. Rempang Island is connected by the 5th Barelang bridge with Galang Island in the South. Galang island has an area of around $80 \mathrm{~km}^{2}$ and is the third-largest island in Batam City. Based on spatial analysis, Galang Island and Rempang Island regions have morphological features in the form of plains and hills with hilly and bumpy variations.

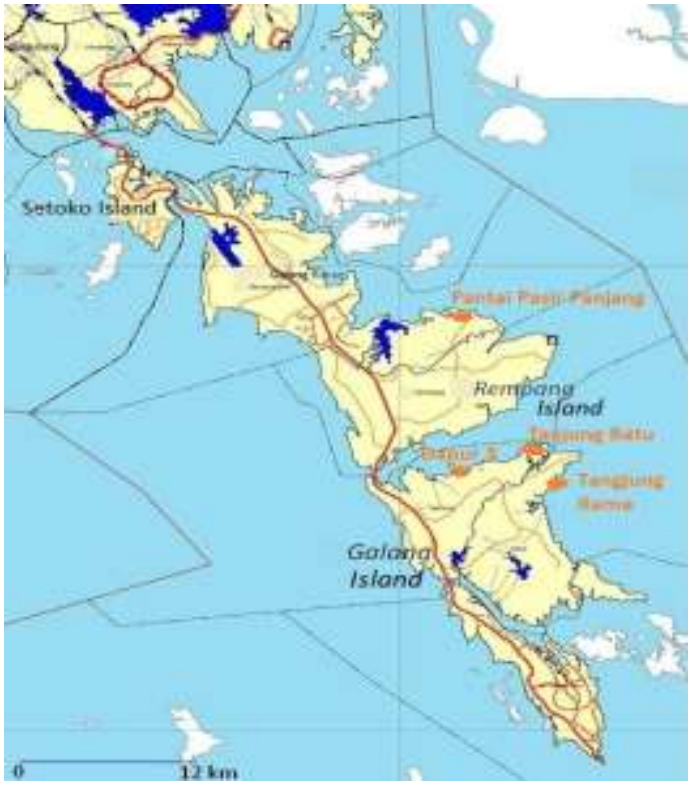

Figure 1.

Rempang and Galang Island Research Locations, Batam City, ${ }^{5,15}$

\section{HYDROGEOLOGICAL CHARACTERISTICS FOR THE SITE OF NPP}

In selecting an NPP site, hydrogeological aspect must be considered ${ }^{6}$. A special aspect that needs to be considered in the presence of NPP is the potential for the release of large amounts of radioactive material. In the perspective of nuclear safety, NPP has the aim of protecting society and the environment due to the release of radioactive material both during normal operations and accidents ${ }^{16,17)}$. Site characteristics that affect the safety of the installation or transfer of radioactive material are the considerations in selecting potential sites for NPP. Therefore, hydrogeology aspect needs to be evaluated. Evaluation of hydrogeological characteristics includes determining the transport paths and travel time for radioactive material to reach the source of water for community consumption from the point of release ${ }^{11}$.

Hydrogeology is a part of hydrology that studies the distribution and movement of groundwater in the soil or rock layers (generally as aquifers). Hydrogeological data are investigated, which are then collected and presented in the form of maps. Geological data related to the characteristics of surface and groundwater content include rocks that have moderate permeability and porosity ${ }^{18)}$. So that one of the site acceptance requirements for geological formations related to hydrogeological characteristics is rock permeability, and that 
the area is not barren. The permeable geological formations are aquifers and aquitards.

An aquifer is a layer that holds water, where the component of groundwater flow is assumed to be horizontal because the vertical component of groundwater flow is very small compared to horizontal one ${ }^{19)}$. Aquifers generally have permeable formations or groups of geological formations that are from unconsolidated sand, gravel, sandstone, limestone, fractured volcanic rocks and rock crystals. The aquifer is water saturated and has a hydraulic conductivity value $\mathrm{K}$ (in $\mathrm{m} / \mathrm{sec}$ ) so that it can store and drain sufficient quantities of water. $K$ is a parameter that depends on the nature of the porous and fluid media. In aquifers, rainwater enters the ground through the pores of sand and rocks ${ }^{20}$ ). Sufficient groundwater is defined when the availability of groundwater has a depth of about $3 \mathrm{~m}$ below the surface of the land. Therefore, one of the data that needs to be collected to support site feasibility is information on aquifer distribution, which is depicted in a map ${ }^{21)}$.

Aquifers can be used for domestic, urban, industrial or irrigation water supply, so aquifer supply lines provide a potential path for the transfer of radioactive material to humans in the event of a nuclear reactor accident. The potential for radiological and non-radiological contamination will affect the groundwater that is around the location of the NPP and outside the site boundary, so it needs hydrogeological data ${ }^{22)}$.

Like aquifers, aquitards are layers or rock formations that can store water but can only supply a limited amount of water, have a small hydraulic conductivity value so that water flow through the layer is slow. In aquitards, groundwater flow is assumed to be vertical because the horizontal flow component is very small compared to the vertical flow component.

Groundwater moves following a pressure gradient (flowing from high to low pressure), often through channels in the fracture pathway ${ }^{23)}$. Groundwater comes to the surface in the form of a spring, which is a means of identifying what is happening to the groundwater system ${ }^{24)}$. Geological information on groundwater is one of the data that needs to be considered in the feasibility of a nuclear power plant site, but the presence of groundwater flow does not hamper site selection but must be considered in determining potential sites.

\section{RESULT AND DISCUSSION}

The site survey of NPP in Riau I have been conducted in 2015 and 2017. Based on electricity needs supported by demographic data in regencies and cities in Riau Islands Province, the highest needs and the latest industrial developments are in Batam City, so the priority for the NPP site is the Barelang Island. In the Barelang Island area there are 9 districts namely Galang, Sei Beduk, Sagulung Nongsa, Batam Kota, Batu Ampar, Lubuk Baja, Sekupang, Batu Aji, and Bengkong ${ }^{25)}$. In the initial evaluation for geological aspects, land use conditions, geography and topography, as well as demography, Galang sub-district has several potential areas of interest, namely in Tanjung Kelingking, Sijantung Village, Tanjung Batu and Tanjung Rame. Based on the ranking and weighting of seismic aspects which includes surface faulting, seismicity, and geology/lithology, some potential areas are identified in Pasir Panjang Beach, Tanjung Batu, Dapur 3 and Tanjung Rame, so this study limits the locations in Galang subdistrict, Rempang Island and Galang, Batam City. Areas that have an aquifer or at least aquitard is an area that can be selected as an area that supports the feasibility of a potential nuclear power plant site.

The potential area has soil structure in the form of rock weathering and is quite old. The area has a relatively low landscape and topography forming a wavy pattern that can be proved by the presence of small hills. These small hills have an average topography of approximately $160 \mathrm{~m}$ above sea level. The low surface of the topography forms low groundwater flow conditions, so groundwater flow will follow the topographic slope. The research area has an environmental balance that is built from the forms of hills, wetlands, swamps, and gardens, which are still well preserved. With increasing industry and population growth, groundwater is now scarce. Follow-up regional and local investigations related to the presence of groundwater in the potential area needs to be done.

The surface geology map issued by the BP Batam Program and Research and Development Planning Bureau (Figure 2), shows that in the Pasir Panjang, Tanjung Batu, Dapur 3 and Tanjung Rame areas, the surface geology has a soft to a moderate surface layer. The surface geology is composed of soft rock in the form of sandstone, siltstone and tuff sandstone. 


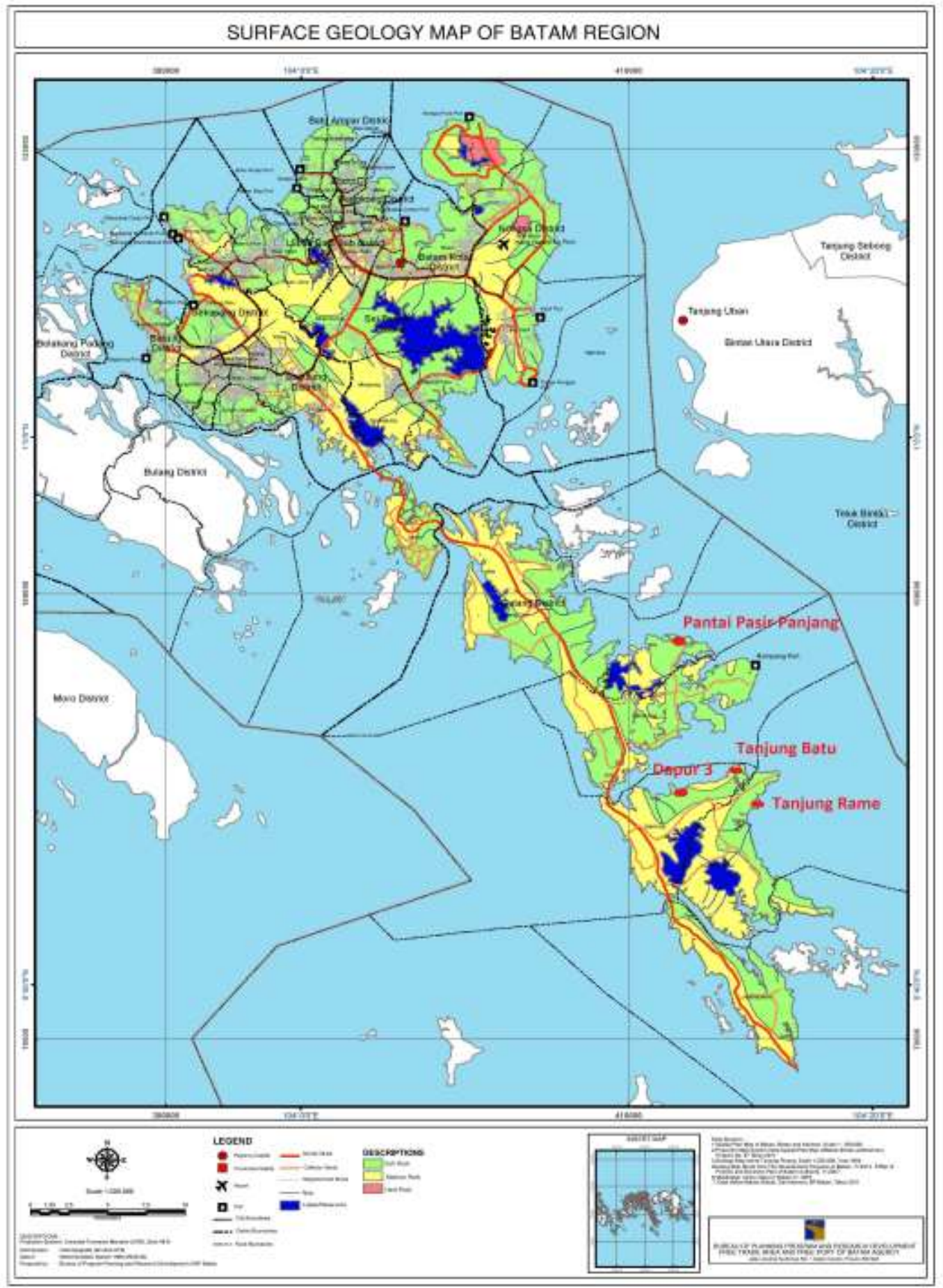

Figure 2.

Surface Geology Map of Batam Region ${ }^{15}$

From the results of geological surveys, it is known that the Rempang-Galang research area is composed of several rock formations that have rock composition as aquifers to store water. This condition is manifested on the surface in the form of sandstone, tuffaceous sandstone, tuff, clay and conglomerates around Rempang.
Groundwater productivity data (Figure 3), shows that in some areas of Galang subdistrict, especially in the northeastern part of Galang Island, and in some areas of Rempang (from north to south) the level of groundwater productivity is low. In the southwestern part of the two islands, groundwater is difficult to find. 


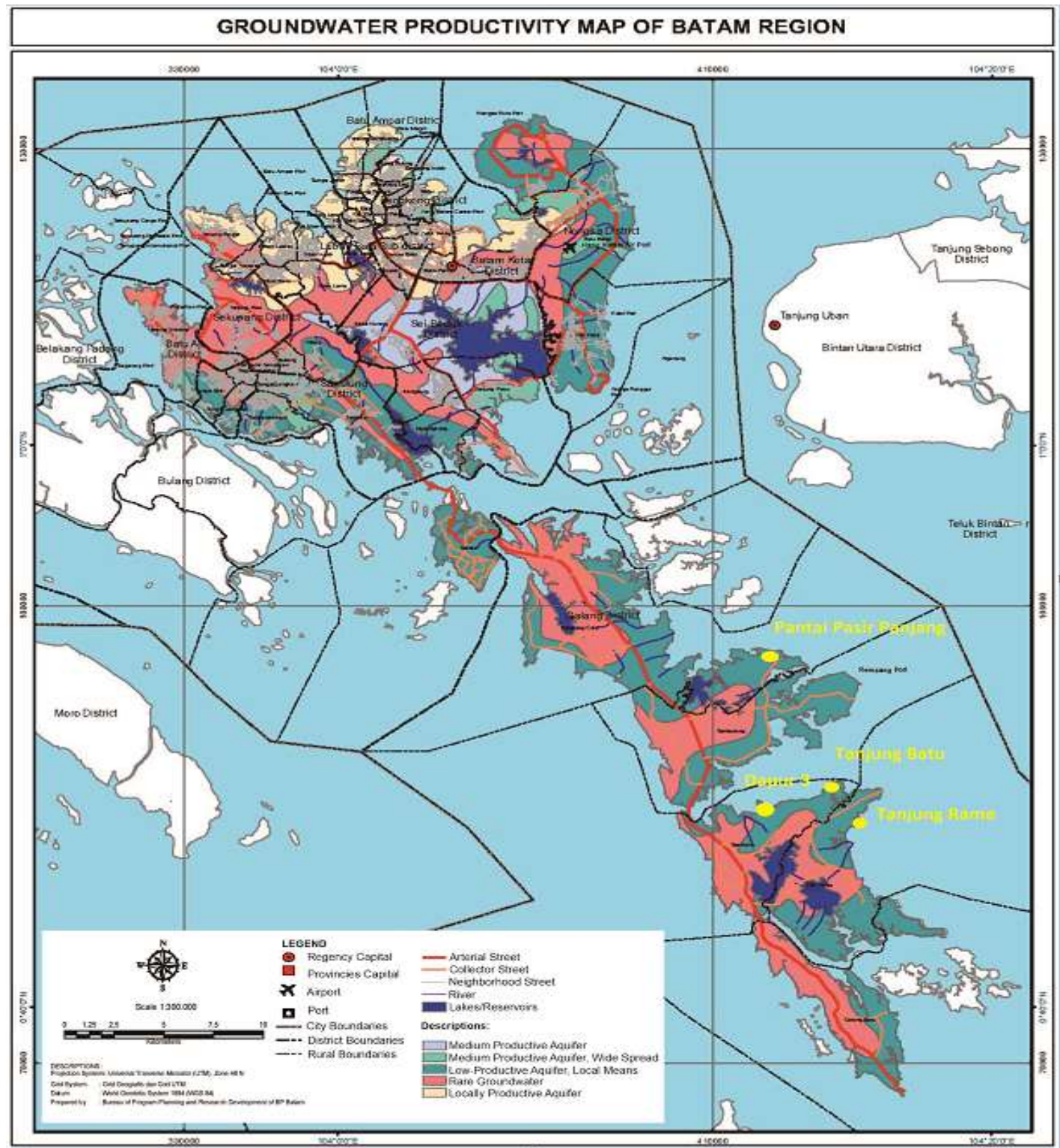

Figure 3.

Map of Batam Region Groundwater Productivity ${ }^{15)}$

Site acceptance from the hydrogeological aspect, other than surface geology, is based on groundwater productivity related to rock porosity. The best site is one that has relatively low to medium rock porosity. At low to medium porosity, groundwater can be stored due to the ability of rocks shows in the level of ease of fluid flowing through these rocks ${ }^{26}$, whereas if porosity is high then groundwater will not be stored. Figure 4 shows the distribution of rock porosity levels. High porosity levels are found in the eastern part of Rempang Island and Galang Island. In the western part of Galang Island, the porosity varies from low to high. Whereas the western part of Rempang
Island has a lower level of porosity than the eastern part.

For considerations relating to the supply of sustainable cooling water needs during the operation of the NPP, in the determination of prospective sites, one general criterion that must also be considered is the distance from the coastline to land which is a maximum of $3 \mathrm{~km}$. The coastline is taken from the point of coast to land and is limited to a radius of 3 $\mathrm{km}$. Based on the results of 2015 research, all the potential area meets the requirements of the distance of coastline to land which is less than $3 \mathrm{~km}^{27,28)}$. 


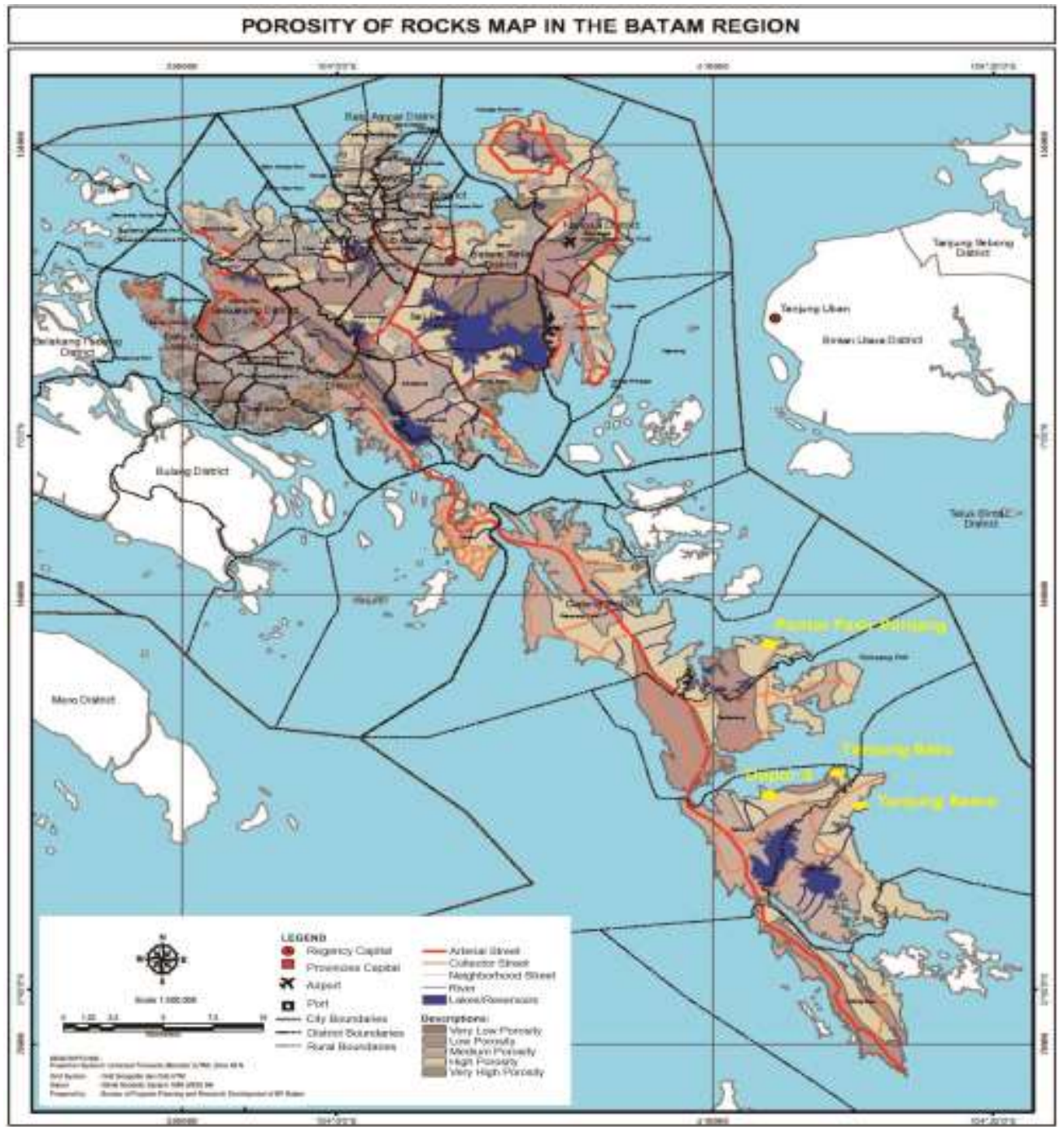

Figure 4.

The Porosity of Rocks in the Batam Region [15]

The level of acceptance of a potential NPP site from hydrogeological aspects in Galang sub-district, Batam City is determined by \% weight and score for the parameters, namely surface geology, groundwater productivity and rock porosity (Tables 1, 2, 3 and 4).

Table 1.

Definition of Score

\begin{tabular}{|c|c|c|c|c|}
\hline \multirow{2}{*}{ No. } & \multirow{2}{*}{ Parameter } & \multicolumn{3}{|c|}{ Score } \\
\hline & & 1 & 2 & 3 \\
\hline 1 & $\begin{array}{l}\text { Surface } \\
\text { Geology }\end{array}$ & Sand & $\begin{array}{l}\text { Sandstone, Clay Stone, } \\
\text { Organic Clay }\end{array}$ & $\begin{array}{l}\text { Granite, diorite, } \\
\text { conglomerate }\end{array}$ \\
\hline 2 & $\begin{array}{l}\text { Groundwater } \\
\text { Productivity }\end{array}$ & $\begin{array}{l}\text { Scarce } \\
\text { Groundwater Area }\end{array}$ & $\begin{array}{l}\text { Aquifers with low local } \\
\text { productivity mean; Moderate } \\
\text { productivity aquifer }\end{array}$ & $\begin{array}{l}\text { Aquifer productivity is } \\
\text { being spread widely; Local } \\
\text { aquifers are productive }\end{array}$ \\
\hline 3 & Rock Porosity & Very High - High & Intermediate & Low - Very Low \\
\hline
\end{tabular}

Weight percentages are based on the weighting factor ${ }^{29)}$ of the parameters, with limits 1-3. Weighting factor based on Site Data Report Newjec. Based on studies that have been done before, this study considers the repellent factor, in this case, the repellent factor is an active fault. However, in Batam, there is no active fault, so that the importance of hydrogeological aspects rises in line with values that are equally important, such as aspects of earthquake, volcano, tsunami or extreme meteorology. 
Table 2.

Weight Percentage

\begin{tabular}{clcc}
\hline No. & \multicolumn{1}{c}{ Parameter } & Weighting factor & $\%$ Weight \\
\hline 1 & Surface Geology & 1 & 16.7 \\
2 & Groundwater Productivity & 3 & 50 \\
3 & Rock Porosity & 2 & 33.3 \\
\hline & Total Weight Value & 6 & 100 \\
\hline
\end{tabular}

Table 3.

Scoring of Hydrogeological Aspects for Potential Areas

\begin{tabular}{|c|c|c|c|c|c|c|c|c|c|c|}
\hline \multirow[t]{2}{*}{ No } & \multirow[t]{2}{*}{ Parameter } & \multirow{2}{*}{$\begin{array}{c}\% \\
\text { Weight }\end{array}$} & \multicolumn{4}{|c|}{ Score } & \multicolumn{4}{|c|}{ Total Score } \\
\hline & & & $\begin{array}{c}\text { Pasir } \\
\text { Panjang } \\
\text { Beach }\end{array}$ & $\begin{array}{c}\text { Tanjung } \\
\text { Batu }\end{array}$ & $\begin{array}{c}\text { Dapur } \\
3\end{array}$ & $\begin{array}{c}\text { Tanjung } \\
\text { Rame }\end{array}$ & $\begin{array}{c}\text { Pasir } \\
\text { Panjang } \\
\text { Beach }\end{array}$ & $\begin{array}{c}\text { Tanjung } \\
\text { Batu }\end{array}$ & $\begin{array}{l}\text { Dapur } \\
3\end{array}$ & $\begin{array}{c}\text { Tanjung } \\
\text { Rame }\end{array}$ \\
\hline 1 & $\begin{array}{l}\text { Surface } \\
\text { Geology }\end{array}$ & 16.7 & 1 & 3 & 3 & 2 & 16.7 & 50.1 & 50.1 & 33.4 \\
\hline 2 & $\begin{array}{l}\text { Groundwater } \\
\text { Productivity }\end{array}$ & 50 & 2 & 2 & 2 & 2 & 100 & 100 & 100 & 100 \\
\hline 3 & Rock Porosity & 33.3 & 1 & 3 & 1 & 1 & 33.3 & 99.9 & 33.3 & 33.3 \\
\hline & & & Total & & & & 150 & 300 & 183.4 & 166.7 \\
\hline
\end{tabular}

Table 4.

Classification $^{29)}$

\begin{tabular}{ccl}
\hline No. & Total Score & \multicolumn{1}{c}{ Classification } \\
\hline 1 & $166.7-300$ & $\begin{array}{l}\text { Potential as a candidate site } \\
\text { based on the hydrogeological }\end{array}$ \\
& & $\begin{array}{l}\text { aspect } \\
\text { No potential as a candidate site } \\
\text { based on the hydrogeological } \\
\text { aspect }\end{array}$ \\
\end{tabular}

Table 3 shows the weighting results for the level of site feasibility based on hydrogeological aspects. Tanjung Batu has a total weight value of 300 (the highest weight value), followed by Dapur 3 with a value of 183.4, Tanjung Rame has a value of 166.7 and Pasir Panjang has a value of 150. Based on these results Tanjung Batu, Dapur 3 and Tanjung Rame can be an option for site acceptance based on hydrogeological aspects. The three regions have surface geology in the form of sandstone, clay and claystone with medium rock porosity and medium groundwater productivity. Whereas Pasir Panjang Beach based on the hydrogeological parameters studied has a lower level of acceptance because it has a high level of porosity of rocks and the productivity of aquifers is being spread widely.

An overlay analysis was performed using the geographic information system (GIS) presented in Figure 5.

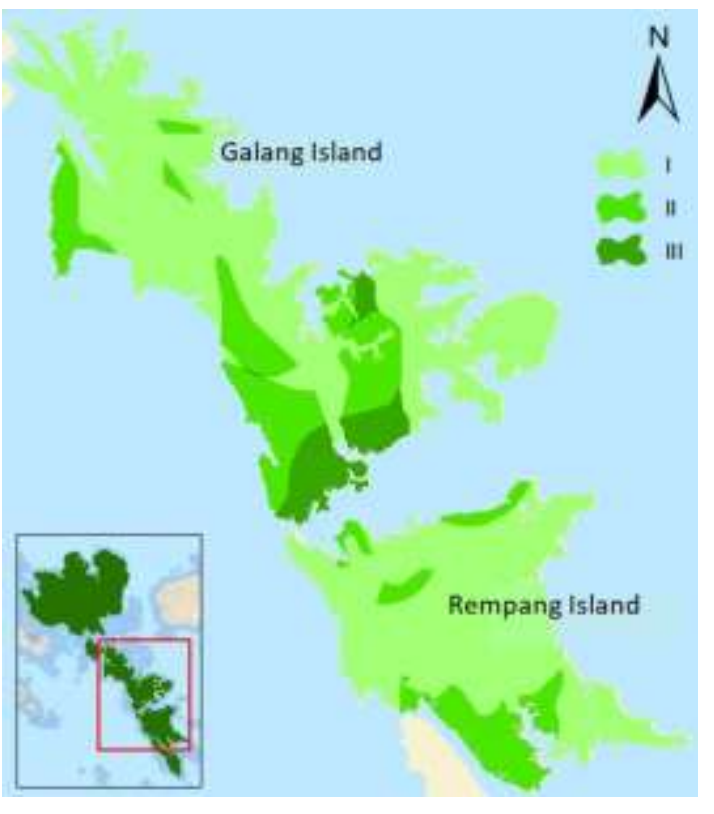

Figure 5.

Distribution of potential NPP Site Based on Hydrogeological Aspects in Galang subdistrict, Batam City 
Caption:

I: Areas with the lowest potential for NPP site based on 3 hydrogeological parameters. The area has very low groundwater potential, including areas where groundwater is scarce, having high to very high rock porosity due to scattered rocks in the form of sand.

II: Areas with moderate potential for NPP sites based on the hydrogeological parameters used. The area has moderate to low groundwater potential with the ability of rocks to pass moderate amount of groundwater.

III: Areas with high potential for NPP site based on low to very low rock porosity and moderate to high groundwater productivity.

These potential sites are the basis of further research, to get the sites of selected candidates. Based on the comparison and ranking of selected candidates the site will be obtained on the site are scale. The site evaluation is then performed to obtain site characteristics and design parameters.

\section{CONCLUSION}

Site acceptance based on hydrogeological aspect has been investigated from surface geology, groundwater productivity and rock porosity. The best site is one that has relatively low to medium rock porosity. At low to medium porosity, groundwater can be stored. Based on the hydrogeological aspect, Tanjung Batu, Dapur 3 and Tanjung Rame can be identified as potential NPP Sites. The three regions have surface geology in the form of sandstone, clay and clayey rock with medium rock porosity level and moderate groundwater productivity. Pasir Panjang Beach based on the hydrogeological parameters studied has a lower level of acceptance because it has a high level of porosity of rocks and the productivity of aquifers is being spread widely.

\section{ACKNOWLEDGMENT}

The author would like to thank the Center for Nuclear Energy Systems - BATAN, who has provided direction in research activities.

\section{REFERENCES}

1. Peraturan Presiden RI, Rencana Tata Ruang Kawasan Batam, Bintan dan Karimun, No. 87, Indonesia, 2011.
2. BP Batam, Kegiatan Studi Awal Rencana Pembangunan PLTN di Kawasan Pulau Rempang dan Galang, Indonesia, MOU SK Kepala BP BATAM No. 77, 2015.

3. Peraturan Presiden RI, Badan Tenaga Nuklir Nasional, No. 46, Indonesia, 2013.

4. PKSEN, Laporan Teknis Akhir Kegiatan Dokumen Dukungan Teknis Survei Tapak PLTN di Kepulauan Riau, Jakarta, 2016.

5. PKSEN, Laporan Teknis Akhir Kegiatan Dokumen Dukungan Teknis Survei Tapak PLTN di Kepulauan Riau, Jakarta, 2017.

6. International Atomic Energy Agency (IAEA), Site Survey and Site Selection for Nuclear Installations, 2015.

7. Rotaru, I., NPP Siting, Annual Joint ICTP/IAEA Nuclear Energy Management School, Trieste, Italy, 5-23 November 2012.

8. Swamy Raju, L., Siting Review of NPP, National Conference on Regulatory Interface, Organised by AERB, Mumbay, 2017

9. Giacinto, J., Ahn, J.H., Barnhurst, D., Mcbride, D.M., Tiruneh, N., and Raione, N.R., Conceptual Groundwater Model Development for New Nuclear, 2nd Joint Federal Interagency Conference, 2010, p.1-12.

10. Basu, P.C., Site Evaluation for Nuclear Power Plants - The Practices, Nuclear Engineering and Design, Vol. 352, October 2019, 110140.

DOI: 10.1016/j.nucengdes. 2019.06.002.

11. International Atomic Energy Agency (IAEA), Dispersion of Radioactive Material in Air and Water and Consideration of Population Distribution in Site Evaluation for Nuclear Power Plants, IAEA Safety Standards Series No. NS-G3.2, 2002.

12. Suntoko, H., Pemilihan Tapak PLTN di Semenanjung Muria, Jurnal Pengembangan Energi Nuklir, Vol. 1, No. 4, Desember 1999.

13. NEWJEC, Site Data Report, Feasibility Study of The First Nuclear Power Power Plants at Muria Peninsula Region Central Java, Newjec, Inc, INPB-Rep-4-Nov, 1996.

14. International Atomic Energy Agency (IAEA), Site Survey and Site Selection for Nuclear Installation, IAEA Safety Standards, Draft Spec - DS433, Revision of IAEA Safety Series No. 50-SG-S9, 1984.

15. BP Batam, Layanan Peta BP Batam, Badan Pengusahaan Kawasan Perdagangan Bebas dan Pelabuhan Bebas Batam, Batam, 2017. 
16. International Atomic Energy Agency (IAEA), Site Evaluation for Nuclear Installations, 2016.

17. Aly, A.I.M., Hussein, R.A., and Nassar, N., Radioactive Dispersion in Groundwater Resulting from Postulated Accident at a Proposed Nuclear Power Plant, North-western Coast of Egypt, Groundwater for Sustainable Development, Vol. 10, April 2020, 100326.

DOI: 10.1016/j.gsd.2019.100326.

18. International Atomic Energy Agency (IAEA), Meteorological and Hydrological Hazards in Site Evaluation for Nuclear Installations SSG-18, 2011.

19. Pirlot, M., and Vincke, Ph., Basic Concepts and Definitions, Semiorders, 1997, p.49-70.

20. Prayogo, T., Kajian Kondisi Air Tanah Dangkal Daerah Wonomarto, Lampung Utara, J. Teknol. Lingkung., Vol. 15, No. 2, 2015, p.107-114.

21. Peraturan Kepala BAPETEN No. 6 Tahun 2014, Evaluasi Tapak Instalasi Nuklir Untuk Aspek Meteorologi dan Hidrologi, Indonesia, 2014.

22. Jacob, P., General Site Suitability Criteria for Nuclear Power Stations, Regulatory Guide 4.7 Revision 3, USNRC, 2014.

23. Boyd, F., Siting of Nuclear Power Plants, Overview Notes, Chulalongkorn University, Bangkok, 1997.
24. Irawan, D.E., Model Hidrogeologi dan Perubahan Sifat Fisika-Kimia Air Tanah pada Sistem Akuifer Endapan Gunungapi Studi Kasus: Zona Mata Air Gunung Ciremai, Jawa Barat, Disertasi Program Studi Doktor Ilmu Geologi, ITB, 2009.

25. BPS, Batam Dalam Angka, Batam, 2016.

26. Ashari, Y., Kajian Hidrogeologi: Karakteristik Akuifer dan Hidrokimia Kawasan antara Kec. Padalarang Ngamprah Kab. Bandung, Jurnal Unisba, Ethos, Vol. III, No. 2, 2005.

27. Suntoko, H., Identifikasi Daerah Interes Calon Tapak PLTN Kalimantan Barat Berdasarkan Kriteria Umum, Eksplorium, Vol. 35, No. 1, 2014, p.57-68.

28. Arianto, S., Studi Awal Rencana Pembangunan PLTN di Kawasan Pulau Barelang (Batam, Rempang, Galang, Laporan Akhir Badab Pengusahaan Kawasan Perdagangan Bebas dan Pelabuhan Bebas BATAM, Kepri-PKSEN BATAN, Jakarta, 2015.

29. Susiati, H., et. al., Aplikasi Data Peginderaan Jauh dan SIG dalam Pemilihan Tapak Potensial PLTN Kalimantan Barat, Jurnal Pengembangan Energi Nuklir, Vol. 17, No. 2, 2015. 